\title{
Titus Phase Archeology at the S. Stockade Site (41TT865) on Tankersley Creek, Titus County, Texas
}

Timothy K. Perttula

Heritage Research Center, Stephen F. Austin State University

Bo Nelson

Heritage Research Center, Stephen F. Austin State University

LeeAnna Schniebs

Follow this and additional works at: https://scholarworks.sfasu.edu/ita

Part of the American Material Culture Commons, Archaeological Anthropology Commons, Environmental Studies Commons, Other American Studies Commons, Other Arts and Humanities Commons, Other History of Art, Architecture, and Archaeology Commons, and the United States History Commons

Tell us how this article helped you.

This Article is brought to you for free and open access by the Center for Regional Heritage Research at SFA ScholarWorks. It has been accepted for inclusion in Index of Texas Archaeology: Open Access Gray Literature from the Lone Star State by an authorized editor of SFA ScholarWorks. For more information, please contact cdsscholarworks@sfasu.edu. 


\section{Titus Phase Archeology at the S. Stockade Site (41TT865) on Tankersley Creek, Titus County, Texas}

\section{Creative Commons License}

\section{(c) (1) \&}

This work is licensed under a Creative Commons Attribution-NonCommercial 4.0 International License 


\title{
Titus Phase Archeology at the S. Stockade Site (41TT865) on Tankersley Creek, Titus County, Texas
}

\author{
Timothy K. Perttula, Bo Nelson, and LeeAnna Schniebs
}

The S. Stockade site was discovered on a small rise (330 feet amsl) in the Tankersley Creek floodplain (Figure 1) during a recent archeological survey for the Texas Department of Transportation (Perttula et al. 2002). Tankersley Creek is a southward-flowing tributary to Big Cypress Creek, and enters that creek's floodplain a few miles below the Lake Bob Sandlin dam. There is a dense concentration of prehistoric archeological sites throughout the Tankersley Creek valley, particularly post-A.D. 800 Caddo Indian sites. This paper discusses the archeology of the S. Stockade site, a Late Caddoan Titus phase settlement.

The rise at the S. Stockade site is grass-covered (with a surface visibility of less than 10\%) (Figure 2a), except along the eroded slopes, where the clay B-horizon subsoil is exposed. The old creek channel immediately to the west of the rise has recently been channelized (Figure 2b), and between the rise and the channelized creek are several low-lying marshy areas with standing water.

Five backhoe trenches excavated on the floodplain rise (BHT $10,12,14,15$, and 17) contained prehistoric artifacts, principally Late Caddoan ceramic sherds. Two of these trenches were on the rise, and the three others were a short distance to the south and east of the rise (see Figure 1). Well-preserved black midden deposits were identified in both backhoe trenches on the rise (Figure 3), and in nearby BHT 17.

In BHT 10 and Unit 349, a 50 x $50 \mathrm{~cm}$ unit screened in $10 \mathrm{~cm}$ levels to recover prehistoric artifacts in a controlled context, the midden deposits (Zone 2) began at the surface or were only shallowly buried by a very dark gray sandy loam Zone 1 (Figure 4). The midden is approximately $50-54 \mathrm{~cm}$

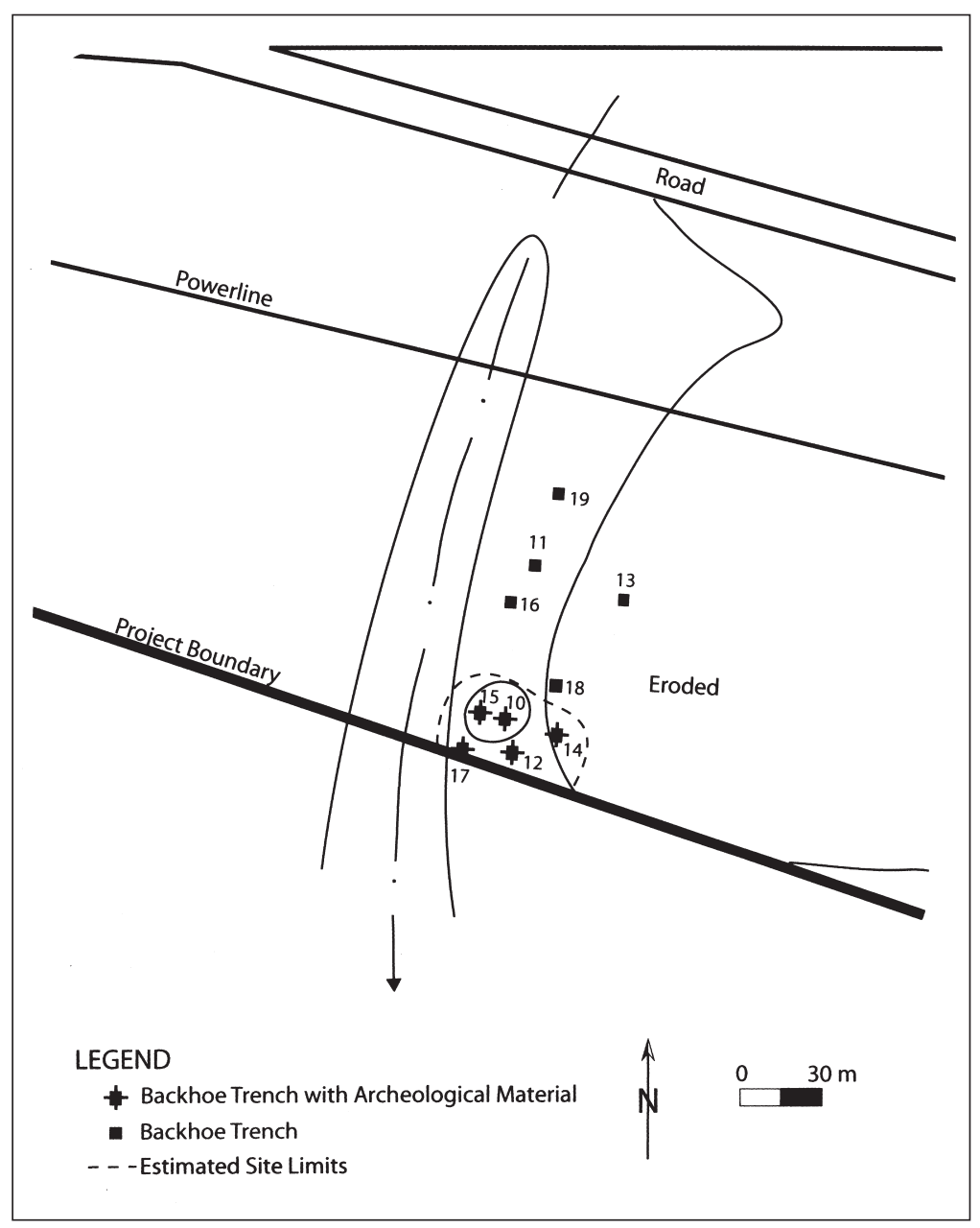

Figure 1. Map of the S. Stockade site (41TT865). 


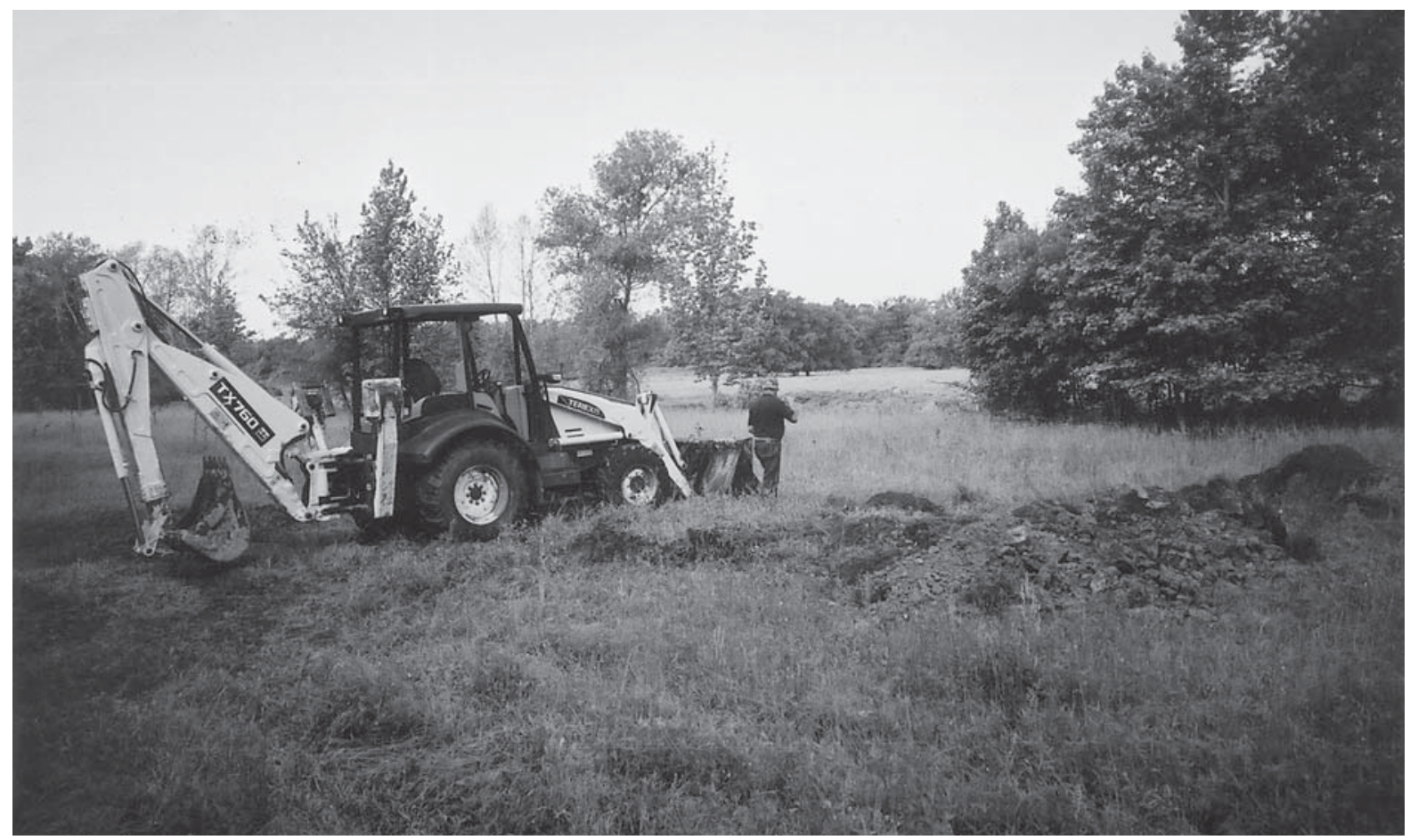

A

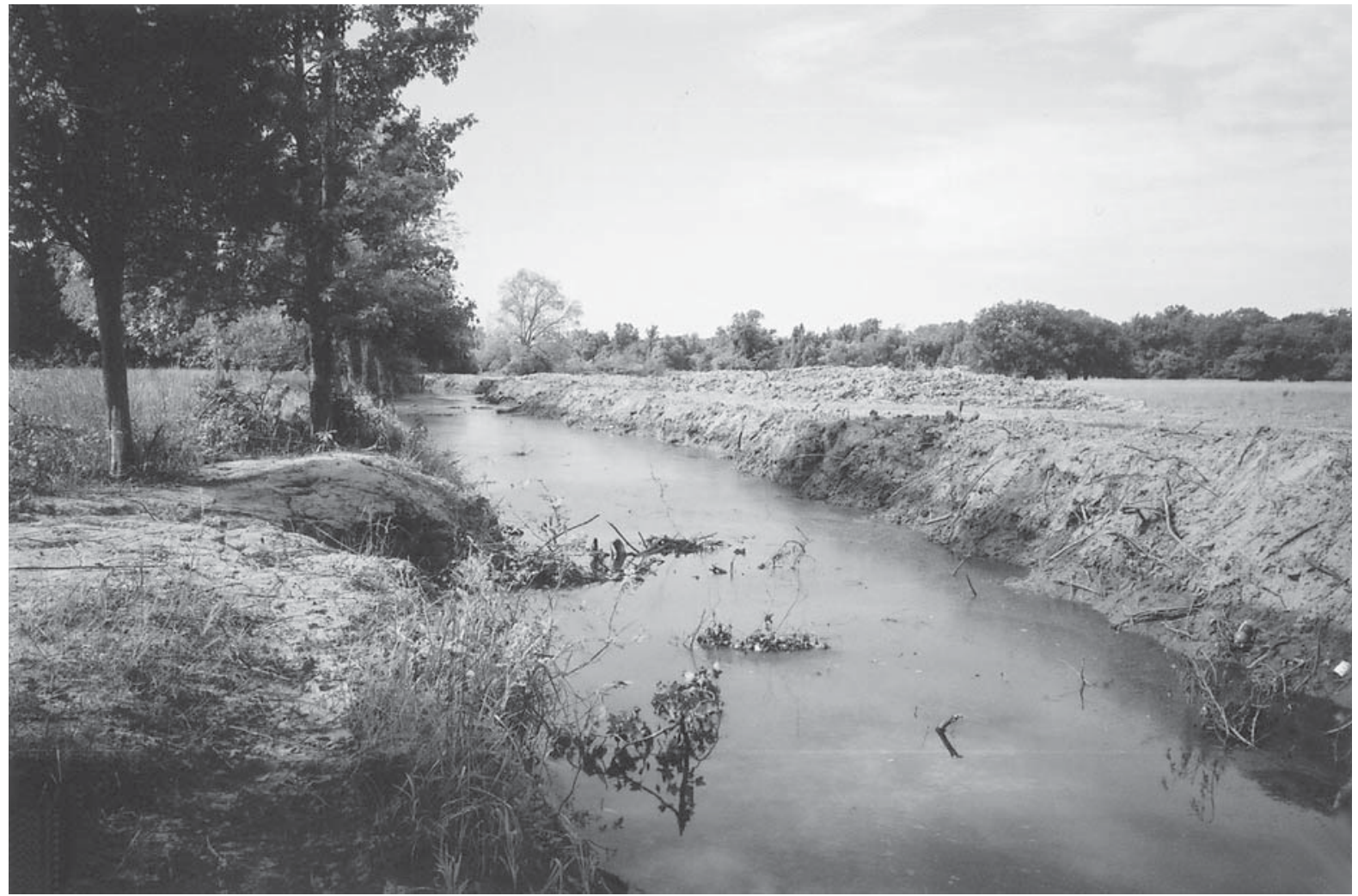

B

Figure 2a. Looking west at backhoe trenching at the S. Stockade site; b, stream channelization, looking south. 


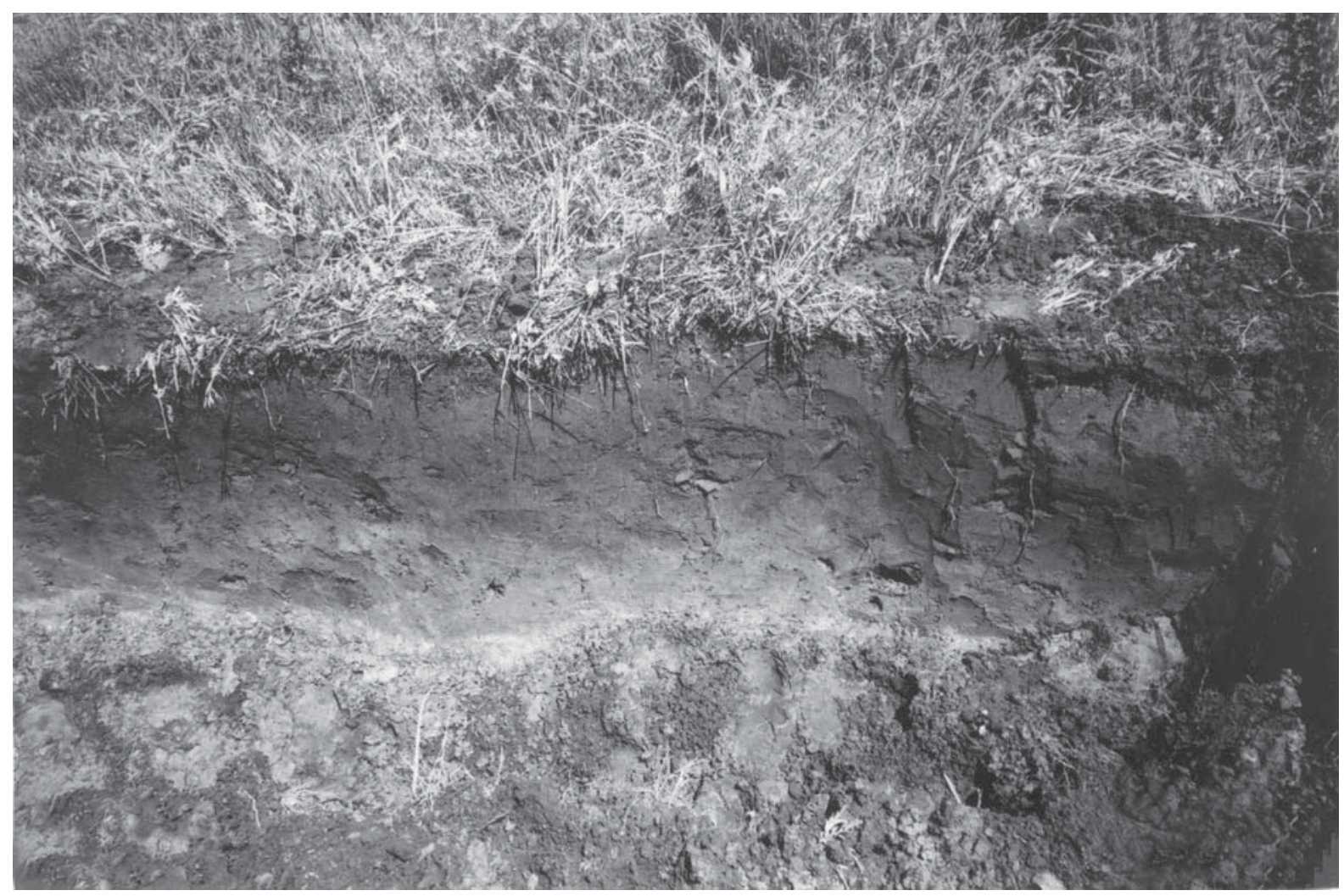

Figure 3. Backhoe trench 15 profile, east wall.

in thickness, and lies atop the B-horizon, a reddish-yellow clay (Zone 3); the midden had a high density of sherds (including several in the profile at 21 and $35 \mathrm{~cm} \mathrm{bs)} \mathrm{and} \mathrm{a} \mathrm{small} \mathrm{amount} \mathrm{of} \mathrm{lithic} \mathrm{debris,} \mathrm{as} \mathrm{well} \mathrm{as}$ charred Carya sp. nutshell and wood charcoal.

The midden deposits in BHT 15, and Unit 354, are buried by $5-25 \mathrm{~cm}$ of very dark grayish-brown (Zone 1) to dark brown (Zone 2) sandy loam sediments (Figure 5; see also Figure 3). These zones are artifact-bearing, but the midden - a black sandy loam (Zone 3) - has abundant sherds, lithic artifacts, small pieces of bone, and wood charcoal and Carya sp. nutshells. The midden is about $15-30 \mathrm{~cm}$ in thickness. Large sherds are visible in the BHT 15 midden profile between $23-48 \mathrm{~cm}$ bs. A small animal bone was visible in the profile at ca. $24 \mathrm{~cm}$ bs (see E on Figure 5). Underlying the midden in BHT 15 is a yellowish-brown sandy loam (Zone 4), and this zone rests on the reddish-yellow clay B-horizon (see Zone 5 on Figure 5); the sandy loam sediments underlying the midden represent the low natural floodplain rise landform that had midden debris eventually deposited on it. Unit 355, a fine-screen column, was also excavated along BHT 15.

BHT 17 was not on the rise, but buried midden deposits were also present here between $33-54 \mathrm{~cm} \mathrm{bs}$ (Figure 6). The midden sediments were a very dark gray (10YR 3/1) sandy loam (Zone 3) with charcoal flecks, and dark gray (Zone 1) and brown (Zone 2) sandy loam A-horizon deposits occur above the midden. A single parallel brushed body sherd was noted in the backhoe trench profile resting at the top of the midden deposit. Like the BHT 15 profile, a ca. $25 \mathrm{~cm}$ thick wedge of sandy loam sediments (dark yellowish-brown in BHT 17) was present below the midden (Zone 4) and above the B-horizon; in BHT 17, the B-horizon was a gray alluvial clay (Zone 5). 
Off the midden, in BHT 12, the artifact-bearing sediments are a very dark gray to dark yellowishbrown sandy loam A horizon about 29-34 $\mathrm{cm}$ in thickness above the B-horizon clay. In BHT 14, the sandy loam sediments are only $19-25 \mathrm{~cm}$ in thickness overlying thick dark grayish-brown and gray clay deposits extending to more than $90 \mathrm{~cm}$ bs.

A large assemblage of Late Caddoan Titus phase ceramics was found at the S. Stockade site during backhoe trench investigations. The assemblage includes 34 decorated sherds, 74 plain sherds, and a single piece of burned clay (a few sherds were also found in the fine-screen column, see below). Ten more sherds were noted in the BHT 10 and BHT 15 backdirt, but they were not collected. They included nine plain body sherds and a single parallel brushed body sherd.

Most of the sherds were collected from units $349(\mathrm{n}=49)$ and $354(n=34)$ in BHT 10 and BHT 15, respectively, and these units in the midden deposits have about 140-200 sherds per square meter. Outside the midden, 50 x $50 \mathrm{~cm}$ units along BHT 12 and BHT 14 have densities of only 4-16 sherds per square meter. By depth, the sherds are concentrated between $10-30 \mathrm{~cm}$ bs ( $60 \%$ of 90 sherds), with another $14 \%$ found from 0-10 cm bs; a few sherds occur as deep as $50-60 \mathrm{~cm}$ bs where the midden was thicker or had been more deeply buried by sediments.

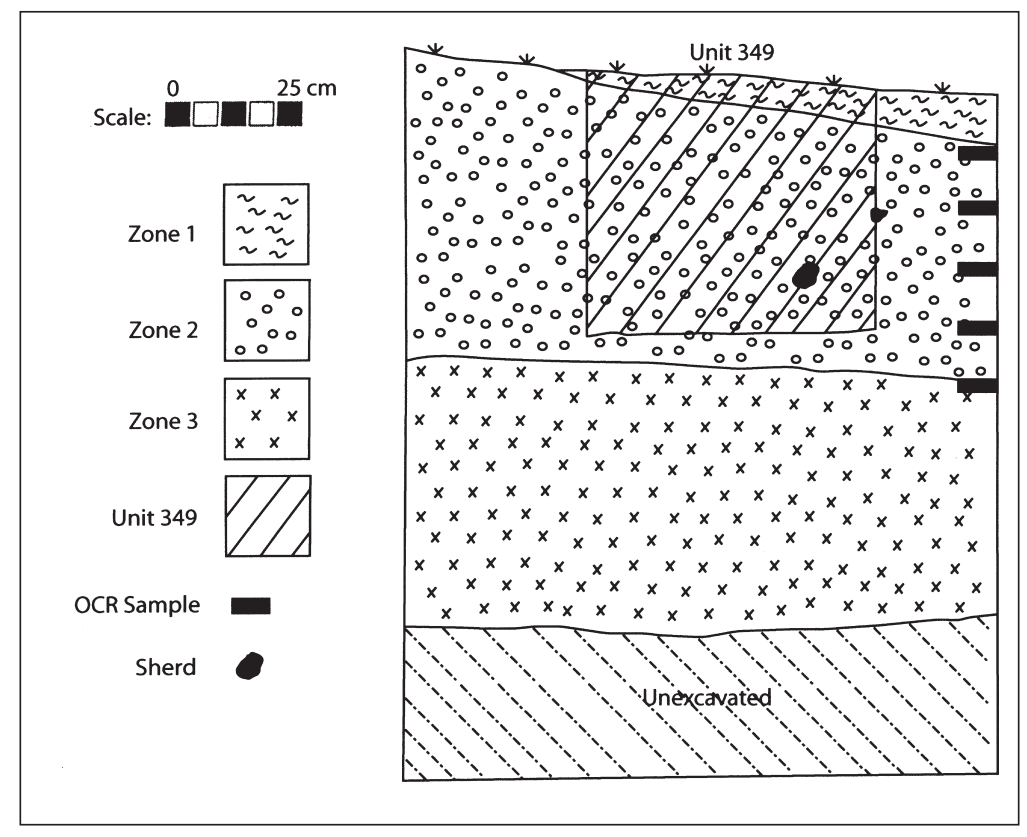

Figure 4. Profile of backhoe trench 10 and Unit 349, S. Stockade site.

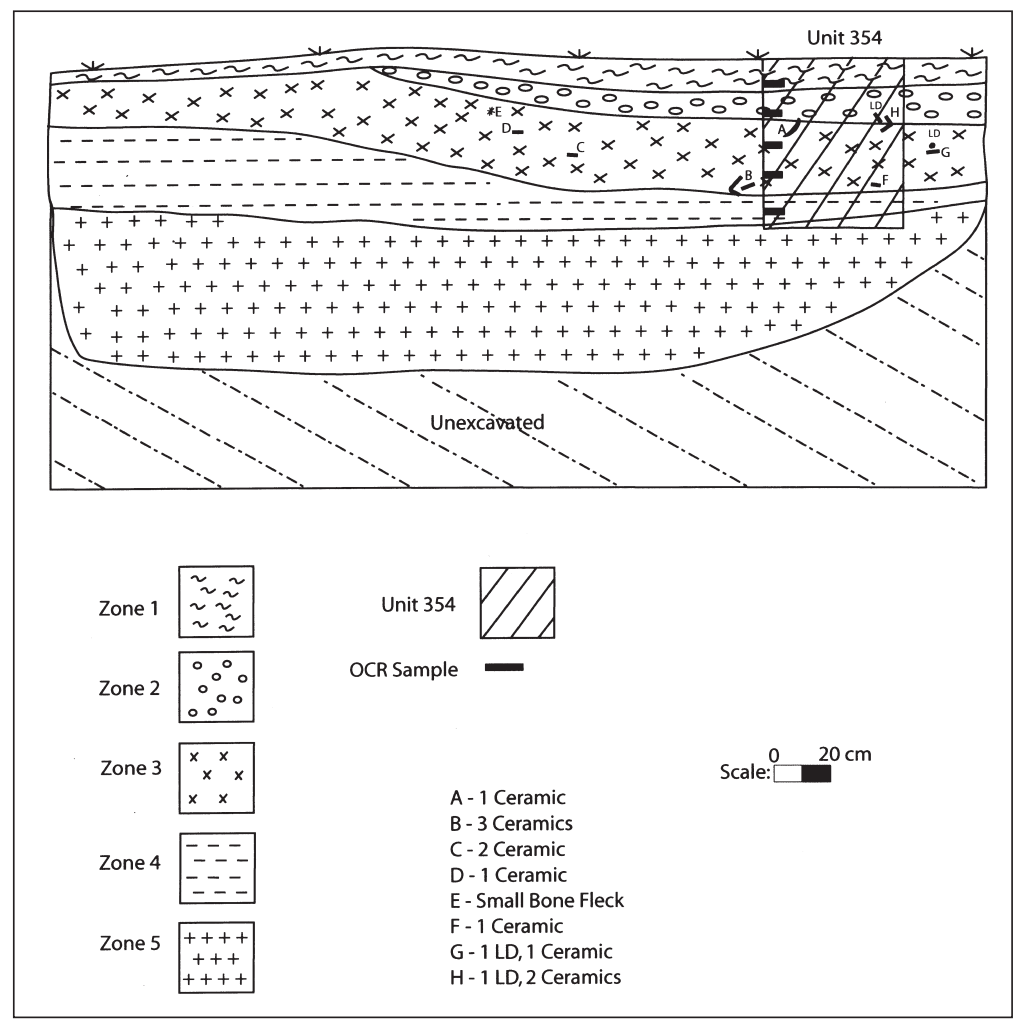

Figure 5. Profile of backhoe trench 15 and Unit 354.

This Titus phase ceramic assemblage is dominated by sherds tempered with grog (95\%), and fully 63\% of the sherds are tempered only with grog. The remainder are tempered with grog and bone $(6.8 \%)$, and 
grog and hematite (14.6\%); almost $11 \%$ are tempered with grog and have abundant charred organic remains preserved in the paste. The non-grog-tempered sherds include crushed bone (2\%), hematite (1\%), and bone-hematite $(1 \%)$; one other sherd has only abundant charred organics, and five other sherds have no apparent temper inclusions. The very high frequency of grog temper-and the concomitantly low amount of bone temper in vessel sherds-is completely consistent with Titus phase assemblages in the Big Cypress Creek basin (see Perttula et al. 1998).

More than $60 \%$ of the sherds have a naturally sandy clay paste, and this appears to be the case for both the plain and decorated sherds and/or vessels from which they derived, including both finewares and utility ware cooking and storage jars. As with most Titus phase ceramic assemblages in the upper part of the Big Cypress Creek basin, most of the sherds are from vessels fired in a reducing environment $(71.7 \%)$, and many of the vessels were subsequently cooled in the open air. The remainder of the sherds are equally split between those fired in an oxidizing environment or incompletely oxidized during firing. A few of the sherds (5.5\%) have a distinctive core or cross-section with an almost completely oxidized core, other than a thin darker and reducing band along either the inner or outer surface of the vessel sherds. It is possible that this darkened band in otherwise completely oxidized vessels may be the product of use for cooking, with the near outer or inner surfaces "blackened by reducing gases from the cooking fire" (Rye 1980:116).

Rim and body sherds are relatively thick for Titus phase ceramics, $6.97 \pm 0.32 \mathrm{~mm}$ for rims $(\mathrm{n}=7)$ and $6.85 \pm 0.77 \mathrm{~mm}$ for body sherds $(\mathrm{n}=96)$. The four base sherds are $11.63 \pm 0.73 \mathrm{~mm}$ in thickness, and they obviously supported large and well-constructed vessels.

The decorated sherds from the S. Stockade site include brushing $(n=10)$, brushed-incised $(n=2)$, incised $(n=5)$, neck banded $(n=1)$, punctated $(n=5)$, and engraving $(n=11)$. The latter sherds $(32 \%$ of the decorated sherds) are from fine ware vessels, principally carinated bowls used for serving foods.

Among the utility ware sherds, the brushed sherds have either parallel $(n=9)$ or overlapping brushing marks (Figure 7g) on the vessel body, and may be from Bullard Brushed, Pease Brushed-Incised, or Maydelle Incised jars (see Perttula et al. 1998). Two other body sherds have parallel brushed-incised decorative elements. The incised body sherds have either sets of parallel incised lines $(n=4)$ or a single straight incised line from an indeterminate decorative element. The one La Rue Neck Banded rim (Figure $7 \mathrm{~h}$ ) has at least two horizontal bands of crimped and unsmoothed coils below the lip of a cooking jar with an everted rim. The punctated sherds are divided between tool $(n=3)$ and fingernail $(n=2)$ punctates (Figure 


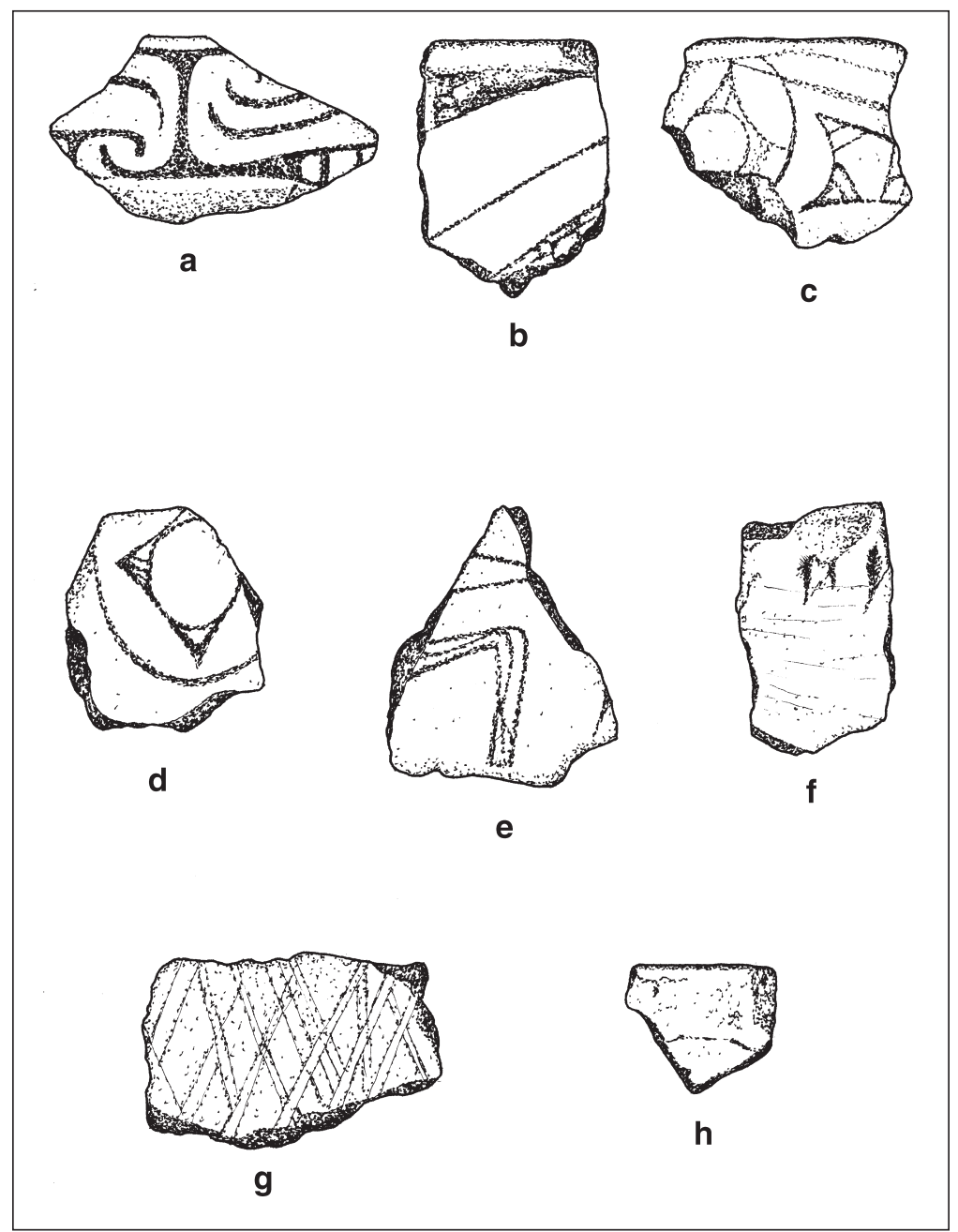

Figure 7. Decorated Sherds from the S. Stockade Site: a, Taylor Engraved; b-e, Ripley Engraved; f, fingernail punctated; g, overlapping brushed; h, neck-banded. Provenience: a, BHT 15, 33 cm; b-c, Unit 354, 10-20 cm; d, BHT 15, D; e, Unit 354, 20-30 cm; f, BHT 15, G; g, Unit 354, 30-40 cm; h, Unit $354,0-10 \mathrm{~cm}$. Scale is $1: 1$.

ure 7a; see also Suhm and Jelks 1962). Taylor Engraved vessels appear to have been made and used after ca. A.D. 1550 by Titus phase groups (see Perttula 1992: Appendix A), and become more abundant in mortuary contexts that postdate ca. A.D. 1600. The absence of the pendant triangle motif-perhaps the best stylistic element signifying a post-A.D. 1600 Titus phase occupation (see Perttula et al. 1998) in the Big Cypress Creek basin-in the four different Ripley Engraved vessels from the S. Stockade site suggests that it may have been occupied between ca. A.D. 1550-1600, immediately after the initial contacts between the Caddo in the region and the Spanish Moscoso entrada.

All four of the Ripley Engraved sherds have a scroll motif (cf. Thurmond 1990:Figure 6), and two specifically have the scroll and circle motif (see Figure 7c-d). This particular engraved motif is relatively abundant only in later Titus phase contexts (see Perttula 1992:Apendix A), and thus is consistent with the age range suggested above based on the occurrence of the Taylor Engraved vessel, although this motif is less frequent than the pendant triangle motif. This motif is also commonly seen in many upper Big Cypress 
Creek Titus phase vessels from mortuary contexts, including sites in the Tankersley Creek and Three Basins subcluster sites discussed by Thurmond (1990; see also discussion in Perttula et al. 1998:252-253).

One Kent dart point was found in Unit $349(0-10 \mathrm{~cm}$ bs). It was made from a local brown chert, has a parallel stem, a flat base, and minimal barbs, with a resharpened and serrated blade. Kent points are commonly found in Woodland period contexts in Northeast Texas archeological sites, and thus its recovery here suggests that the S. Stockade site was also used in the Woodland period. The point measures $32.0 \mathrm{~mm}$ in length, $18.0 \mathrm{~mm}$ in width, $7.2 \mathrm{~mm}$ in thickness, and has a stem width of $15.0 \mathrm{~mm}$.

There are two cores and 18 pieces of lithic debris from the site, with the majority of the lithic artifacts found in units 349 and 354, the 50 x $50 \mathrm{~cm}$ units excavated along BHT 10 and BHT 15, respectively (see Figures 4 and 5). They come from $0-60 \mathrm{~cm}$ bs, but the majority were recovered between 0 $30 \mathrm{~cm}$ bs in and above the midden deposits.

The core fragments are from Unit $349(20-30 \mathrm{~cm} \mathrm{bs})$ and Unit $354(40-50 \mathrm{~cm} \mathrm{bs})$. Both are quartzite, and one has been heat-treated; it also has a small area of cortex (2\%) on one face, and the other probably represents a fragment from an exhausted core, from which all the cortex had already been removed by knapping.

The lithic debris is exclusively local raw materials, including quartzite ( $\mathrm{n}=11,45 \%$ cortical), Ogallala quartzite $(n=2)$, and petrified wood $(n=5,80 \%$ cortical $)$; the proportion of petrified wood lithic debris $(25 \%)$ is higher here than any of the other U.S. 271 Mt. Pleasant Loop sites. Fifty percent of the lithic debris is cortical, hinting at the importance of initial lithic reduction activities-perhaps to produce useful flakes for tools - and a similar proportion of the lithic debris (73\% quartzite and 50\% of the Ogallala quartzite) has evidence of heat treatment.

The midden deposits also had a small amount of quartzite fire-cracked rock $(\mathrm{n}=2,53.3 \mathrm{~g})$ from Unit $353(0-10 \mathrm{~cm}$ bs) and from the BHT 15 profile (artifact G, see Figure 5).

Wood charcoal $(\mathrm{n}=15)$ and charred Carya sp. nutshells $(\mathrm{n}=3)$ were recovered from three different $50 \times 50 \mathrm{~cm}$ units at the S. Stockade site. These remains occurred between $10-50 \mathrm{~cm}$ bs, namely in the Late Caddoan Titus phase midden deposits preserved at the site.

As part of the work at the site-which included the hand excavation of several 50 x $50 \mathrm{~cm}$ units along certain backhoe trenches to recover archeological materials from controlled contexts-a single $40 \times 40 \mathrm{~cm}$ fine-screen column (Unit 355) was excavated adjacent to Unit 354 in BHT 15. The midden sediment matrix from the column was water-screened through 1/16-inch mesh hardware cloth, and the resulting residue was processed to recover any archeological materials present in the midden. The purpose of the fine-screen column was to more precisely determine the density of cultural materials in the midden itself, and better assess the quality and quantity of any preserved animal bones and charred plant remains. The column was excavated in three levels: $0-10 \mathrm{~cm}, 10-20 \mathrm{~cm}$, and $20-35 \mathrm{~cm}$ bs. The first level-above the middencontained no archeological materials of any kind when it was first screened through 1/4-inch hardware cloth, and thus a fine-screen sample was not processed from the level. The second and third levels were in the midden deposit, and fine-screen column samples were obtained from them.

A variety of archeological materials were recovered from midden deposits in Unit 355, including lithics, ceramic sherds, burned clay, animal bone, charred nutshells, and wood charcoal. There were eight 
pieces of lithic debris, equally divided between quartzite $(n=4)$ and petrified wood $(n=4)$. Seventy-five percent of the lithic debris came from the $20-35 \mathrm{~cm}$ bs sample. The density of lithic debris in this midden column is 48 pieces per $\mathrm{m}^{2}$, and 200 pieces per $\mathrm{m}^{3}$.

There were 20 pieces of burned clay, weighing $19.7 \mathrm{~g}$. Almost $90 \%$ of the burned clay by weight, and $80 \%$ by frequency, came from the $20-35 \mathrm{~cm}$ bs fine-screen sample. The overall density of the burned clay is 120 pieces and $118.2 \mathrm{~g}$ per $\mathrm{m}^{2}$, and 500 pieces and $492.5 \mathrm{~g}$ per $\mathrm{m}^{3}$.

Including sherdlets $(n=6)$, a total of 27 sherds were found in Unit 355 . About $56 \%$ of the sherds are from $10-20 \mathrm{~cm}$ bs. The density of sherds in the Titus phase midden is 162 per $\mathrm{m}^{2}$ and 675 sherds per $\mathrm{m}^{3}$.

Three of the sherds are decorated: a parallel incised body sherd $(10-20 \mathrm{~cm})$, a parallel brushed body sherd $(20-35 \mathrm{~cm})$, and a rim sherd $(20-35 \mathrm{~cm})$ with tool punctates below the lip and diagonal incised lines on the rim itself. Similar decorated sherds were found at the S. Stockade site in the $50 \times 50 \mathrm{~cm}$ units, in the backhoe trench profiles, and in the backhoe trench backdirt.

Almost $95 \%$ of the 18 small pieces of animal bone were found between $20-35 \mathrm{~cm}$ bs. All are burned. The density of bone is ca. 112 pieces per $\mathrm{m}^{2}$ and 450 pieces per $\mathrm{m}^{3}$.

One very small unidentifiable fragment from an indeterminate vertebrate was found at $10-20 \mathrm{~cm}$ bs (Table 1). The remaining pieces came from $20-35 \mathrm{~cm}$ bs, and were comprised of eight indeterminate vertebrate bones, seven small mammal bones, and two pieces of turtle shell. The unidentifiable small mammal remains are not identifiable beyond size and class because the absence of diagnostic attributes prevented specific identification. Based on size, these may be the remains of a rabbit or squirrel, as both are easily procured by hunters, and such remains have frequently been found in prehistoric Caddo faunal assemblages. Turtles are also common in Caddoan faunal collections. All of the faunal specimens are burned white, probably the result of trash disposal after processing. The small faunal sample from the S. Stockade site most likely represents subsistence debris.

Wood charcoal was abundant in the midden deposits, and a total of $15.4 \mathrm{~g}$ was found in the fine-screen column. About $57 \%$ of the wood charcoal is from the $10-20 \mathrm{~cm}$ fine-screen sample. The density of wood charcoal is $92.4 \mathrm{~g}$ per $\mathrm{m}^{2}$ and $385 \mathrm{~g}_{\text {per }} \mathrm{m}^{3}$.

Charred Carya sp. nutshells were also present in the Titus phase midden deposits. A total of 25 pieces $(1.1 \mathrm{~g})$ was recovered in the fine-screen column, with $80 \%$ by number and $91 \%$ by weight coming from the $20-35 \mathrm{~cm}$ bs sample. The density of nutshell is 150 pieces and $6.6 \mathrm{~g} \mathrm{per} \mathrm{m}^{2}$ and 625 pieces and 27.5 g per $^{3}$.

Table 1. Faunal Recovery from the S. Stockade Site, Backhoe Trench 15, Unit 355.

\begin{tabular}{|llllllll|}
\hline Unit & cm bs & Qty & Taxon & Element & Burn & Wt/g & Comments \\
\hline 355 & $10-20$ & 1 & unidentifiable & unid & white & 0.01 & fine screen \\
355 & $20-35$ & 2 & turtle & shell frags. & white & 0.1 & fine screen \\
355 & $20-35$ & 7 & small mammal & unid & white & 0.1 & fine screen \\
355 & $20-35$ & 8 & unidentifiable & unid & white & 0.1 & fine screen \\
\hline
\end{tabular}


The Titus phase midden at the S. Stockade site (41TT865) contains abundant archeological materials based on the processing and sorting of a fine-screen column in Unit 355. Sherds and wood charcoal are most abundant in the upper part of the midden (10-20 cm sample)—while still common in the lower 20-35 $\mathrm{cm}$ sample — but all other archeological materials (animal bone, nutshell, lithic debris, burned clay) are much more abundant in the lower part of the midden in this one sample. It is reasonable to conclude that the 20-35 cm bs fine-screen sample is from the best preserved part of the Titus phase midden.

\section{CONCLUSIONS}

The S. Stockade site is a well-preserved Late Caddoan Titus phase midden deposit in the Big Cypress Creek basin. The investigations summarized here recovered ceramic, lithic, faunal, and paleobotanical materials from a ca. A.D. 1550-1600 occupation. The small size of the settlement suggests that the S. Stockade site is a farmstead affiliated with a larger local community in the Big Cypress Creek valley.

\section{ACKNOWLEDMENTS}

We thank Dr. Nancy A. Kenmotsu and Mike Jordan of the Texas Department of Transportation for permission to publish the results of our investigations at the S. Stockade site in Caddoan Archeology. Clay Schultz prepared the site map and profiles, and Nancy Resee prepared the sherd illustrations.

\section{REFERENCES CITED}

Perttula, T. K.

1992 “The Caddo Nation": Archaeological and Ethnohistoric Perspectives. University of Texas Press, Austin.

Perttula, T. K., B. Nelson, and T. C. Schultz

2002 Archeological Survey of the U.S. 271, Mount Pleasant Loop, Titus County, Texas for the Texas Department of Transportation. Archeological \& Environmental Consultants, LLC, Austin.

Perttula, T. K., M. Tate, H. Neff, J. W. Cogswell, M. D. Glascock, E. Skokan, S. Mulholland, R. Rogers, and B. Nelson

1998 Analysis of the Titus Phase Mortuary Assemblage at the Mockingbird or "Kahbakayammaahin” Site (41TT550). Document No. 970849. Espey, Huston \& Associates, Inc., Austin.

Rye, O. S.

1980 Pottery Technology: Principles and Reconstruction. Taraxacum, Washington, D.C.

Suhm, D. A. and E. B. Jelks (editors)

1962 Handbook of Texas Archeology: Type Descriptions. Special Publication No. 1, Texas Archeological Society, and Bulletin No. 4, Texas Memorial Museum, Austin.

Thurmond, J. P.

1990 Archeology of the Cypress Creek Drainage Basin, Northeastern Texas and Northwestern Louisiana. Studies in Archeology 5. Texas Archeological Research Laboratory, The University of Texas at Austin. 